\title{
The environmental imprints and complexes of social dynamics in rural Africa: cases from Zimbabwe and Ghana
}

\author{
Jennifer A. Elliott *, Michael Campbell \\ School of the Environment, University of Brighton, Brighton BN2 4GJ, UK \\ Received 11 September 2000; in revised form 30 July 2001
}

7 Abstract

This article analyses land use and vegetation change in the savanna contexts of central Zimbabwe and coastal Ghana. The results

of analyses based on field surveys, time series aerial photographs/satellite images and GIS methods challenge current assumptions of linear vegetation change under social dynamics in these two contexts. The evidence from these areas rather points to multi-directional and patch dynamic change. It is thus concluded that more detailed and broadly based studies are necessary to enable more insightful and effective management of land use issues. (c) 2001 Elsevier Science Ltd. All rights reserved.

Keywords: Africa; Vegetation; GIS; Narrative; Multi-directional change; Patch dynamic change

\section{Introduction}

The African landscape has been interpreted and reinterpreted over the last four centuries, with variable results. In the 20th century, a generalised paradigm emerged that linked linear environmental change (usually deforestation and resultant soil erosion) with population. So powerful have the resultant images of environmental change in Africa been, that they achieved the status of 'received wisdom' according to Leach and Mearns (1996) and became 'common knowledge among development professionals in African governments, international donor agencies and non-governmental organisations' (p. 1). Yet, whilst deforestation and soil loss continue to be important contemporary issues in African livelihoods, interventions in resource management and environmental policies more widely, are generally considered to have had only 'patchy successes' (Batterbury and Bebbington, 1999, p. 285).

This paper is a contribution to the growing literature that illustrates the complex dynamics of social and ecological change in Africa. Recent studies, such as that of Fairhead and Leach (1995) in Guinea and Tiffen et al. (1994) in Kenya have been important in redressing the predominant 'crisis narratives' of environmental change,

\footnotetext{
${ }^{*}$ Corresponding author.

E-mail address: j.a.elliott@bton.ac.uk (J.A. Elliott).
}

in providing evidence, for example, of forest expansion and soil conservation under increased human management in areas previously believed to be degraded landscapes. In particular, such work has been central in exposing the plurality of interests surrounding contemporary resource issues and the potential of longer term historical analysis in revealing the patterns and driving forces of environmental change. However, more case study research is needed which incorporates further historical and time-series data sets (Leach and Mearns, 1996, p. 30) and in particular, comparative research is required that goes beyond exploring narrative and counternarrative based on single studies.

The paper also explores new plural methodologies for investigating landscape change and in particular exemplifies the use of GIS technologies in illuminating multidirectional socioenvironmental change. As Haberl et al. (2001) have summarised, 'by its very nature, the study of changes in land use and land cover is an interdisciplinary endeavour' (p. 3) that 'requires bridging the gap between social science, natural science and the humanities' (p. 6). However, the conceptual and methodological challenges of realising what Batterbury et al. (1997) term 'hybrid research' on landscape change are substantial. Klepeis and Turner (2001), for example, note that much of the science of global and environmental change has not connected well to date with the rich historical-based scholarship on changing human-environment conditions and landscapes' (p. 28). Yet as 
68 Beinart (2000) has suggested, historians themselves have

69 often been 'uneasy about incorporating environmental

70 questions into their work' (p. 269), preferring to engage

71 with the 'essentially corrective and anti-colonial ap-

72 proach' (p. 270) of African history and fearing the

73 'strong environmental determinism' evinced by some

74 earlier Western intellectual traditions (p. 269). However,

75 Beinart goes on to identify the many ways in which

76 African and environmental history would be better in-

77 formed through an engagement with a 'more sophisti-

78 cated and multi-faceted science' (p. 295) rather than a

79 simple rejection of scientific methodologies. As Haberl

80 et al. (2001) suggest, such thinking is causing historians

81 to reach out to new techniques including GIS, for

82 analysing landscape change.

83 The need to frame an understanding of land use 84 changes at any point in time within a longer history of 85 society-environment interactions is now well accepted 86 as central to more effective environmental policy making 87 (Batterbury and Bebbington, 1999). Time series aerial 88 photographs are a significant source of such historical 89 transformations in Africa. In combination with detailed 90 field surveys, aerial photography was important in es91 tablishing the counter narratives of landscape change in 92 the work cited above for Guinea and Kenya, for ex93 ample. However, the degree of quantification within 94 these studies was low, relying in the main on the quali95 tative appraisal of successive sets of photography. Au96 thors such as Sullivan (1996) in Namibia, Crummey 97 (1998) in Ethiopia and Lindblade et al. (1998) in 98 Uganda have similarly utilised detailed social survey and 99 aerial photography to question unilinear processes of 100 landscape change.

101 Other works to date that have documented multi102 directional changes have tended to be based on change 103 detection using satellite-derived images (Singh, 1989, 104 Collins and Woodcock, 1996). Similarly, whilst many 105 other works have used GIS methods to allow detailed 106 quantification of landscape feature change, they have 107 been used in the main to emphasise sequential, per108 centage change in classified features and the primary 109 focus has been towards constructing new visual models 110 for the enhancement of image interpretation and anal111 ysis as the key to more effective monitoring and under112 standing. Examples are the works of Millington et al. 113 (1992) on general land use change in sub-Saharan Africa 114 and Nsiah Gyabaah (1992) on desertification in 115 Northern Ghana.

116 Few of these works to date, however, have explicitly 117 documented multi-directional, patch dynamic changes 118 as in the case studies presented here. Patch dynamic 119 vegetation change refers to vegetation change that is 120 locationally differentiated (for example, deforestation 121 and reforestation in patches) and may be periodically 122 discontinuous (possibly due to human activities). Multi123 directional change therefore describes vegetation change that is not unilinear, but may include increases and reductions in species numbers and/or vegetation forms rather than simple reductions or increases. Therefore, while changes such as deforestation may be documented by percentage change, the extent of the landscape features that replaced, or were replaced by particular wooded landscapes have not been revealed. A focus on patch dynamic change also enables the identification of the extent of locational variation that may underpin the gross land use changes seen.

A further limitation of previous works in this field of multi-directional landscape change has been the relative failure to articulate sufficiently the contextual variables that influence environmental change i.e. those features that may have a particular relationship with the processes for change (for example, topography, ecology, location and socioeconomic factors) that influence the speed and direction of possibly locally specific changes. For Vadya and Walters (1999) this is symptomatic of what they consider is a general overemphasis currently given to 'politics' within political ecology, that tends to miss 'the complex and contingent interactions of factors whereby actual environmental changes often are produced' (p. 167). Their call is for political ecology to become reacquainted with the 'externally-real' biophysical processes referred to above by Batterbury et al. (1997). Arguably, such work has become more important with the paradigmatic shift that has occurred in the ecological sciences over the last 30 years that, in short, has moved the emphasis to non-equilibrium dynamics over earlier 'balance of nature' perspectives. Within the 'new ecology', many of the central concepts and models of ecological theory have been recast such as those relating to mechanistic succession, vegetation climaxes and human/nature separation. Within the new paradigm, non-linear and multi-directional ecological change are to the fore (Pickett et al., 1992) which may be subject to 'multiple interpretations' (Scoones, 1997). Notions of irreversibility (Solbrig, 1993) are central and chaotic change can now be viewed as intrinsic rather than necessarily due to external interference (Nicolis, 1994).

There is now much evidence that social science is increasingly articulating with these same concerns of uncertainty and complexity and is leading to more inclusive social analysis and alternative readings of social and ecological theory that has both practical and political implications (Rowe, 1997; Scoones, 1997; Sullivan, 1996). Scoones (1999) suggests that one of the most significant bodies of work that 'has the potential to take central elements of new ecological thinking seriously' ( $p$. 490) is that which is concerned with the processes of landscape change, 'developed in detailed and situated analysis of "people in places", using, in particular, historical analysis as a way of explaining environmental change across time and space' (p. 490). However, 'the way environmental change is conceptualised is crucial' 
180 (Scoones, 1997, p. 162) and there is a need for further 181 studies that emphasise 'non-linear, multi-directional, 182 punctuated. . .dynamic and non-equilibrium possibilities 183 for processes of transformation' (p. 162).

184 This article seeks to contribute to the continued re185 thinking of 'orthodox' notions of landscape change in 186 Africa via new case study materials from two location187 ally distinct but manifestly related African forest/sav188 anna mosaic contexts: in the Tokwe region of central 189 Zimbabwe and the Tuba/Aplaku plains of the Coastal 190 Savanna of Ghana (see Figs. 1 and 2, respectively). The 191 principal objective of this research was the description, 192 quantification and analysis of patch dynamic, discon193 tinuous and multi-directional vegetation change across 194 the study sites, via a multiple tool analysis (using GIS 195 methods, time series images, field measurements and 196 social surveys) and with an explicit concern also to 197 identify the contextual environmental factors and land198 scape features driving these changes. The broader rela199 tions of these social and environmental contexts have 200 been described elsewhere (for Zimbabwe see Elliott, 2011995 and McGregor, 1995; for Ghana see Campbell, 202 1998), but the comparative analysis of dynamics within 203 a broader African context (taking several local snap204 shots) is not a common theme in the literature as already 205 identified.

\section{2. Methodology}

207 The data presented here are drawn from two larger 208 research projects investigating the sustainability of en209 vironmental changes under a government-directed re210 settlement programme (in the Zimbabwean case) and 211 under spontaneous population expansion and move-

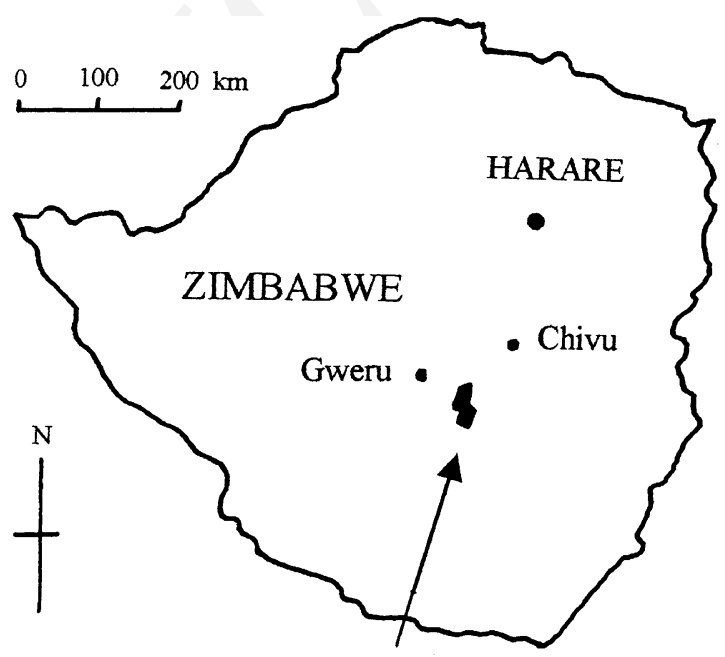

Tokwe Resettlement Scheme area

Fig. 1. The Tokwe area of Zimbabwe.

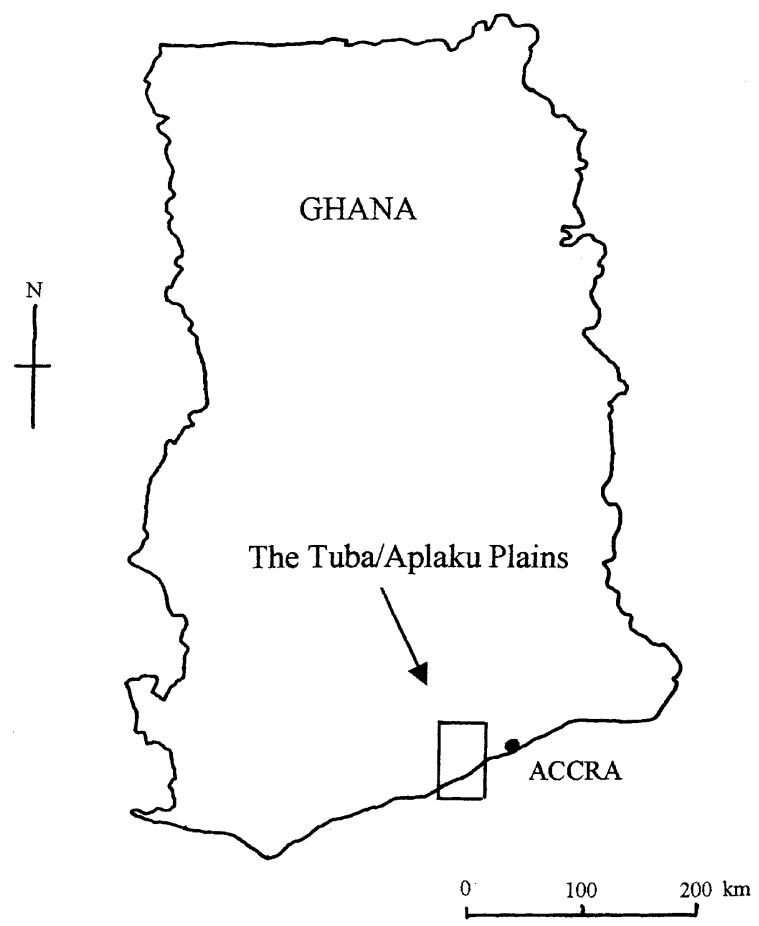

Fig. 2. The Tuba/Aplaku plains of coastal Ghana.

ment in the Ghanaian example. The primary research was carried out in 1992-1993 and 1995-1996, respectively. A core resource within both studies was timeseries panchromatic aerial photographs. In Zimbabwe, systematic blanket photography at the 1:25,000 scale was flown at approximately five-year intervals from 1963 to the late 1980s during the dry season, May-October. This enabled sets of photography to be accessed for the case study areas across the period of population resettlement, namely 1972 (8 years prior to resettlement) and 1985 (5 years following resettlement). In the Ghanaian case study, the analysis was based on black and white aerial photographs at the scale of 1:10,000 flown in September 1960 (towards the end of the second rainy season) combined with data from a SPOT satellite image dated September 1998.

Aerial photographs enable the identification of changes in visible representations of plant structures (crown height, position, perimeter canopy dynamics and open spots, etc., assessed by the parameters of tone, shape, texture, size and pattern of the features) over time giving powerful impressions of phytogeographical change (Roscoe, 1960; Rubben, 1960; Salami, 1999). Land use characteristics can similarly be readily identified at these scales on the same basis of patterns and tone, for example. Whilst the generally higher resolution of aerial photographs over satellite images has been cited as an advantage (Ihse, 1994; Innes, 1998), supporting information is essential for detailed feature identification in both cases (Jensen, 1996; Hertwitz et al.,
212

213

214

215

216

217

218

219

220

221

222

223

224

225

226

227

228

229

230

231

232

233

234

235

236

237

238

239

240

241 
242 1998). The concern within this research was to investi243 gate landscape changes that cover a period within the 244 living memories of land users rather than a more ex245 tended period of time (as could be revealed by further 246 historical sets of photography or the incorporation of 247 more recent satellite images). Such 'shorter term envi248 ronmental histories' have been identified as particularly 249 useful for identifying those forces driving contemporary 250 environmental transformations and of changes in the 251 intensity and patterns of land use change (Batterbury 252 and Bebbington, 1999).

253 For each set of aerial photographs and in both case 254 studies, landscape features were identified and mapped 255 from the contact prints using the conventions described 256 in Table 1. Although these stages were carried out as 257 elements of wider, separate research projects, the con258 ventions of aerial photograph and satellite interpreta259 tion are well established as identified above. All such 260 land use maps were subsequently scanned and converted 261 for use with the IDRISI GIS system for the purposes of 262 this research as reported here. This GIS software then 263 enabled the use of the Area, Overlay and Cross-tabu264 lation functions to investigate linear and multi-direc265 tional land use changes within the two case studies.

266 In each case study, field surveys and semi-structured 267 interviews were conducted with residents in the area 268 centring on the factors underpinning contemporary land 269 and resource use decision-making and perceptions of 270 environmental changes. In the Zimbabwean research, 271 villages within the wider resettlement scheme were 272 identified randomly. Adult representatives of all house273 holds in those villages were then interviewed subse274 quently. In total, 550 households were visited on a single 275 occasion as part of the widest research, although this 276 paper draws on the particular cases of two villages 277 comprising 79 households. In the Ghanaian case, the 278 wider research worked with several members of over 150 279 households identified randomly within the villages of the 280 Tuba/Aplaku region. This paper draws on all these in281 terviews but distinguishes between those residents of
Aplaku/Densu and those from Kokrobite/Oshiyie (approximately one-third and two-thirds of the total respondents, respectively).

The hypothesis is that this GIS approach in combination with plural methodologies for accessing social data gives sufficient groundwork to answer, at least partially, complex socioenvironmentally based questions that would be less completely answered by more narrow methods. Evidently, the dates of the time series images and the field survey were not perfectly established in either case study. However, it is asserted here that the extensive area covered by the images and the comprehensive focus of the field survey enable good insights to the linkages between the social activities described and the environmental changes documented by the GIS methods that offer a basis for reliable generalisations to be made about socioenvironmental relations in the areas under study.

3. Case study 1. The Savanna/woodlands of central Zimbabwe

\subsection{A narrative}

The core narrative of environmental change in Zimbabwe (formerly the British colony of Rhodesia) has historically been one of linear, demographically related degradation. The main problems identified during the early part of the 20th century were deforestation and soil erosion (McGregor, 1995; Whitlow, 1988). Although initially, it was largely settler activities of agriculture and mining that were suggested as underpinning these environmental changes, the issues of deforestation and soil erosion were quickly reinterpreted as problems caused by peasant farmers (McGregor, 1995; Elliott, 1991). Factors for this shift were largely political and reflected events in the international economy and the wider mindset of the colonialist scientific universalism seen in Africa generally at this time, rather than an objective
300

301

302

Table 1

Vegetation classification for aerial photograph analysis

\begin{tabular}{|c|c|c|}
\hline Zimbabwean vegetation classification & Ghanaian equivalent & Details \\
\hline Woodland & Tree/shrub & $>50 \%$ canopy of trees \\
\hline Open woodland & Tree/shrub & $10-50 \%$ canopy of trees \\
\hline Bushland & Tree/shrub & $\begin{array}{l}>50 \% \text { canopy of trees, smaller than those of woodland and including } \\
\text { bushes and scrub }\end{array}$ \\
\hline Open bushland & Grass/shrub & $10-50 \%$ canopy of small trees including bushes and shrub \\
\hline Grassland & Grass/shrub & Mainly grass covered but including areas of scattered trees and vleis \\
\hline Cultivation & Cultivation & Includes all areas showing evidence of present or past cultivation \\
\hline- & Developers & $\begin{array}{l}\text { Areas visibly modified for building purposes. Rectangular bare soil plots } \\
\text { connected by networks of dirt paths }\end{array}$ \\
\hline Water bodies & - & Dependent on water levels at time of photography \\
\hline Settlement & Settlement & Areas of current habitation and close environs \\
\hline- & Other & Including beach areas and road networks \\
\hline
\end{tabular}


318 worsening of the environmental situation nationally in 319 Rhodesia (Beinart, 1984; Phimister, 1986). Increased 320 compulsion and enforcement associated with the con321 servation effort in the country did little to address the 322 real needs of African farmers or the environment (Elli323 ott, 1995).

324 The introduction of colonialist land policies that 325 concentrated Africans in reserves and provided the 326 sources of migratory labour for capitalist production 327 elsewhere in the economy, undoubtedly created over328 crowding and environmental degradation in the com329 munal sector (Scoones, 1995; Cliffe, 1988a). When 330 Zimbabwe attained independence in 1980, a major issue 331 was the relief of population congestion in communal 332 areas through the resettlement of the population and the 333 creation of a settled peasantry through the requirement 334 for such settlers to engage in 'full time' farming. How335 ever, despite that fact that environmental issues were 336 principal factors in the rationale for and the arguments 337 against land reform, the monitoring of the environ338 mental impacts of the resettlement programme over its 33920 year history remains particularly lacking (Elliott, 340 1994). By 1996, 71,000 families largely from the com341 munal areas had been resettled to former European342 owned commercial farmlands (Kinsey, 1997). Further 343 measures designed to reduce land pressure were the 344 improved infrastructure, credit, marketing and exten345 sion services in communal areas considered widely to 346 underpin the production improvements amongst small 347 scale African farmers in the country, once heralded as 348 'Africa's success story' (Cliffe, 1988b).

349 However, not all appraisers were satisfied with these 350 methods for deriving relief from environmental degra351 dation. The The Commercial Farmers Union (1991, p. 352 1), for example, noted that except for a "few notable 353 cases" the result of resettlement was "a serious loss of 354 productivity, denudation of resources, insufficient in355 come and even food aid being required by settlers'. 356 Similarly, Kinsey (1997, p. 174) has confirmed that the 357 land reform programme was "widely criticised, both 358 from within the government and by outside observers' including on the basis of the insufficient understanding of the environmental impacts of resettlement.

Enhancing the pace of land transfers in Zimbabwe remains central for ensuring social, economic and political stability in the country (GoZ, 2001; World Bank, 1999). Since the launch of the "second phase" of land reform and resettlement in 1998, substantially new models for land acquisition and land use planning have been forwarded in recognition of the need to accelerate the delivery of lands, to develop more optimum land use and production options and to promote participation amongst wider stakeholders. However, the land issue in Zimbabwe currently remains highly contested at the local, national and international scales as evidenced by extensive farm invasions in early 2000 , by legal disputes concerning compulsory acquisitions of land and by the fluctuating commitment of donor resources. Furthermore, pressures on the natural resources of resettlement scheme areas are increasing (Harts-Broekhuis and $\mathrm{Hu}-$ isman, 2001). These patterns confirm the timeliness of further study of the outcomes of resettlement to date.

\subsection{Time series images and environmental change}

The Tokwe Intensive Resettlement Area was one of the earliest resettlement scheme areas established by the independent government of Zimbabwe. Between 1981 and 1987, over 1000 families were voluntarily recruited and moved largely from the neighbouring communal areas of Shurugwi and Chirumanzu to 34 newly created village areas within the area of former European owned farmlands. The analysis here focuses on two villages, namely Devon Ranch and The Falls, located in the central and southern regions of the scheme area, respectively.

The climate of the region is semi-arid with a single rainy season occurring typically between October/November and March/April. Rainfall varies from around $600 \mathrm{~mm}$ annually in the south of the Tokwe scheme area to $750 \mathrm{~mm}$ in the north. Soils are mainly coarse-grained shallow sands and loamy sands, which have low inher-

Table 2

Percentage land feature change in Tokwe villages, 1972-1985

\begin{tabular}{|c|c|c|c|c|c|c|}
\hline \multirow[t]{2}{*}{ Landscape features } & \multicolumn{3}{|c|}{ Devon Ranch } & \multicolumn{3}{|c|}{ The Falls } \\
\hline & 1972 & 1985 & $\%$ Change & 1972 & 1985 & $\%$ Change \\
\hline Woodland & 47.0 & 42.1 & -4.9 & 28.6 & 29.8 & 1.2 \\
\hline Open woodland & 6.2 & 2.7 & -3.5 & 24.8 & 25.6 & 0.8 \\
\hline Bushland & 0 & 0.3 & 0.3 & 10.6 & 0.8 & -9.8 \\
\hline Open bushland & 0.9 & 6.1 & 5.2 & 2.2 & 5.5 & 3.3 \\
\hline Settlement & 0.1 & 0.6 & 0.5 & 0 & 1 & 1.0 \\
\hline Water & 0 & 0 & 0 & 0.3 & 0.5 & 0.2 \\
\hline Grassland & 45.8 & 35.6 & -10.2 & 29.2 & 25.1 & -4.1 \\
\hline Cultivation & 0 & 12.6 & 12.6 & 4.2 & 12.0 & 7.8 \\
\hline Total & 100 & 100 & & 100 & 100 & \\
\hline
\end{tabular}


398 ent fertility and water holding capacity, based on an 399 underlying geology of granite with intrusions of dolerite. 400 Most of the area lies at between 1000 and $1100 \mathrm{~m}$ above 401 sea level and falls within 'agro-ecological' region III, 402 determined on the basis of soils and rainfall character403 istics. The vegetation is dominated by miombo wood404 land, (typical of a large portion of southern, central and 405 eastern Africa) comprising largely Brachystegia spici406 formis, Julbernardia globiflora and Brachystegia boehmii, 407 alongside some Mopane and Acacia.

408 Livelihoods in the area are based almost wholly on 409 rainfed agricultural production. Conditions for maize 410 (the staple) or tobacco (a principal cash crop in Zim411 babwe) are marginal and semi-extensive livestock pro412 duction is a more suitable option in the light of severe 413 mid season dry spells. In continuity with the communal 414 areas from which people were resettled, trees/woodlands 415 are closely linked into the cropping and livestock man416 agement systems.

417 Table 2 displays the linear changes in land use in the 418 two case study villages as quantified through the aerial 419 photograph and GIS analyses. As seen, there were sig420 nificant differences between the villages in terms of the woodland status prior to population movement and in the changes over the period of resettlement. In Devon Ranch, where initial woody cover was more extensive at the time of designation, there has been a small reduction in the area covered by woodland (47-42\%), a $10 \%$ decrease in grassland and a significant increase in area covered by open bushland (from less than $1 \%$ to over $6 \%$ ). In The Falls, the total area under woodland actually increased slightly as did the open woodland and open bushland. There was a significant reduction in bushland (from $10 \%$ to less than 1\%) and a smaller decline in grassland (from approximately $30-25 \%$ ).

However, the limitations of the information presented in Table 2 (i.e. linear expressions of environmental change) are apparent when the data is presented in the form of multi-directional matrices as in Tables 3 and 4 . The matrices based on a cross-tabulation function of IDRISI, document the total values for 1972 and 1985 figures (the bottom row and the extreme right column, respectively) and each column gives the percentage of the 1972 figure that changed into the variable in the rows (the 1985 figures). For example, the figures in the woodland column show the percentages of the total
421

422

423

424

425

426

427

428

429

430

431

432

433

434

435

436

437

438

439

440

441

442

443

Table 3

Transitional matrix of landscape change in Devon Ranch 1972-1985

\begin{tabular}{|c|c|c|c|c|c|c|c|c|}
\hline \multirow{2}{*}{$\begin{array}{c}\text { Landscape features } \\
\text { (1985) }\end{array}$} & \multicolumn{7}{|c|}{ Landscape features (1972) } & \multirow{2}{*}{$\begin{array}{l}\text { Total } \\
(1985)\end{array}$} \\
\hline & Woodland & \begin{tabular}{|l|}
$\begin{array}{l}\text { Open } \\
\text { woodland }\end{array}$ \\
\end{tabular} & Bushland & \begin{tabular}{|l|} 
Open \\
bushland
\end{tabular} & Settlements & Grassland & Cultivation & \\
\hline Woodland & \multirow{2}{*}{\multicolumn{2}{|c|}{ 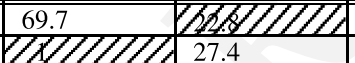 }} & 0 & $13617 / 1 / 17$ & 0 & 16.6 & 0 & 42.1 \\
\hline Open woodland & & & 0 & 0 & 0 & 1.1 & 0 & 2.7 \\
\hline Bushland & \multicolumn{2}{|c|}{ 10477\ 0} & 0 & 0 & 0 & 0.4 & 0 & 0.3 \\
\hline Open bushland & \multirow{2}{*}{\multicolumn{2}{|c|}{ 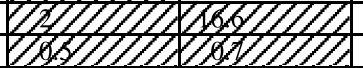 }} & 0 & 51.4 & 100 & 7.8 & 0 & 6.1 \\
\hline Settlements & & & 0 & 0 & 0 & 0.7 & 0 & 0.6 \\
\hline Grassland & \multicolumn{2}{|c|}{10020101080717} & 0 & 18.5 & 0 & 53.9 & 0 & 35.6 \\
\hline Cultivation & \multirow{2}{*}{\multicolumn{2}{|c|}{$\frac{\mid 6.0}{47.0}=\frac{367}{6.2}$}} & 0 & 0 & 0 & 19.5 & 0 & 12.6 \\
\hline Total (1972) & & & 0 & 0.9 & 0.1 & 45.8 & 0 & 100 \\
\hline
\end{tabular}

Deforestation, $\square$ Reforestation.

Table 4

Transitional matrix of landscape change in The Falls 1972-1985

\begin{tabular}{|c|c|c|c|c|c|c|c|c|c|}
\hline \multirow[b]{2}{*}{$\begin{array}{c}\text { Landscape features } \\
\text { (1985) }\end{array}$} & \multicolumn{8}{|c|}{ Landscape features (1972) } & \multirow[b]{2}{*}{$\begin{array}{l}\text { Total } \\
\text { (1985) }\end{array}$} \\
\hline & Woodland & $\begin{array}{l}\text { Open } \\
\text { woodland }\end{array}$ & Bushland & $\begin{array}{l}\text { Open } \\
\text { bushland }\end{array}$ & Settlements & Water & Grassland & Cultivation & \\
\hline Woodland & 52.2 & 31.2 & 12.3 & 21.7 & 0 & 0 & 16.7 & 10.4 & 29.8 \\
\hline Open woodland & $110 / 21 / 1$ & 27.3 & 78.3 & 27.8 & 0 & 0 & 14.5 & 3.1 & 25.6 \\
\hline Bushland & $1 / 1 / 1 / 1 / 1$ & 78181717 & \begin{tabular}{l|l}
0.1 \\
\end{tabular} & 0.8 & 0 & 0 & 0.4 & 6.0 & 0.8 \\
\hline Open bushland & $6 / 86181$ & 7877 & 7087777 & 9.1 & 0 & 0 & 7.5 & 11.4 & 5.5 \\
\hline Settlements & 1861717 & 7177777 & 7174777 & 0 & 0 & 0 & 0.3 & 0 & 1 \\
\hline Water & $101 / 17$ & 0 & 0 & 2.9 & 0 & 62.0 & 0.1 & 0.5 & 0.5 \\
\hline Grassland & $1017>17$ & $73717>7$ & 7621777 & 30.1 & 0 & 38.0 & 43.6 & 26.9 & 25.1 \\
\hline Cultivation & $1961 / 1$ & 986777 & 704787 & 7.5 & 0 & 0 & 16.8 & 41.8 & 12.0 \\
\hline Total (1972) & 28.6 & 24.8 & 10.6 & 2.2 & 0 & 0.3 & 29.2 & 4.2 & 100 \\
\hline
\end{tabular}

Deforestation, 
Table 5

Vegetation dynamics in Tokwe

\begin{tabular}{|c|c|c|}
\hline \multirow{2}{*}{$\begin{array}{l}\text { Vegetation type and land } \\
\text { use }\end{array}$} & \multicolumn{2}{|c|}{ Evidence of dynamics: area and percentage change (1972-1985) } \\
\hline & Devon Ranch & The Falls \\
\hline Woodland & Small reduction $(47-42 \%)$. High overlap $(69.7 \%)$ & $\begin{array}{l}\text { Small increase }(28.6-29.8 \%) \text {. Moderate overlap } \\
(52.2 \%)\end{array}$ \\
\hline Open woodland & Reduction $(6.2-2.7 \%)$. Low overlap (27.4\%) & Small increase (24.8-25.6\%). Low overlap (27.3\%) \\
\hline Bushland & Very small increase $(0-0.3 \%)$ & Large decrease $(10.6-0.8 \%)$. Very low overlap $(0.1 \%)$ \\
\hline Open bushland & Small increase (0.9-6.1\%). Moderate overlap (51.4\%) & Increase $(2.2-5.5 \%)$. Very small overlap $(9.1 \%)$ \\
\hline Grassland & Decrease $(45.8-35.6 \%)$. Moderate overlap (53.9\%) & Decrease (29.2-25.1\%). Moderate overlap (43.6\%) \\
\hline Cultivation & Increase $(0-12.6)$ & Increase (4.2-12.0\%). Moderate overlap (41.8) \\
\hline
\end{tabular}

Table 6

Deforestation/reforestation in different contexts

\begin{tabular}{|c|c|c|c|c|}
\hline \multirow[t]{2}{*}{ Former vegetation } & \multicolumn{2}{|c|}{$\begin{array}{l}\text { Tree loss }(1972-1985) \text { as percentage of total } \\
\text { percentage of features in column }\end{array}$} & \multicolumn{2}{|c|}{$\begin{array}{l}\text { Tree gain (1972-1985) as percentage of total } \\
\text { percentage of features in column }\end{array}$} \\
\hline & Devon Ranch & The Falls & Devon Ranch & The Falls \\
\hline Open bushland & 2 & 2.6 & 0.3 & 1.1 \\
\hline Grassland & 0.3 & 10.4 & 8.3 & 11.3 \\
\hline Cultivation & 10.7 & 5.0 & 0 & 0.8 \\
\hline Settlements & 3.7 & 1 & 0 & 0 \\
\hline $\begin{array}{l}\text { Total tree loss as percent of total } \\
\text { area. }\end{array}$ & 16.7 & 19 & 8.6 & 13.2 \\
\hline
\end{tabular}

444 woodland for 1972 that have changed into the variables 445 in the first column, or remained woodland (the top entry 446 of the first column of Tables 3 and 4). The tables con447 firm the dynamism of the environment and land use 448 across the period and point to the processes of both 449 deforestation and reforestation (identified by shading) 450 occurring in different places that underpin the gross 451 changes identified in Table 2.

452 The variable 'overlaps' recorded in Table 5, confirm 453 that what appeared to be linear deforestation in the 454 Devon Ranch case (indicated, for example, by the re455 duction of woodland of $4.9 \%$ ) was actually the result of 456 locationally distinct increases and reductions in wooded 457 areas; $69.7 \%$ of the area under woodland in 1972 was 458 still woodland in 1985 . However, there was substantial 459 variation in the degree of overlap found in respect to the 460 other land uses and between the two villages studied as 461 also shown in Table 5. For example, the situation in 462 Devon Ranch was less stable in terms of grassland 463 (53.9\% overlap), open bushland (51.4\%) and open 464 woodland $(27.4 \%)$ than in terms of woodland. In The 465 Falls, the woodland overlap was less $(52.2 \%)$, as were 466 the overlaps in terms of all other land uses. Clearly, 467 these patterns are further evidence of the complexities of 468 environmental change enabled through GIS analysis.

469 Table 6 shows the vegetation cover changes described 470 above, documenting tree stand losses and expansion as 471 percentages of the total area under study, differentiated 472 according to the non-forest land categories. Using this method, the gross increases and decreases in various vegetation covers may be presented. This therefore goes further than the presentation in Table 2 (which merely shows gross changes) and also Table 5 (which shows the gross changes as well as the areas of minimal changes, termed overlaps, between the two dates). It also goes further than the presentation in the matrices, which show percentage change within the categories (for example, the percentage area of grass lost to bushland) but not the area thus modified as a percentage of the total area covered. For example, Table 3 shows that in Devon Ranch open bushland lost 30\% of the 1972 coverage $(0.9 \%$ of the total study area) to thicker vegetation. The $30 \%$ change in the $0.9 \%$ open bushland area is presented as approximately $0.3 \%$ in Table 6 : this figure thus represents the total losses of open bushland to forested growths over the period 1972-1985, expressed as a total percentage of the total study area. Clearly, in the case of open bushland, the relatively high percentage change translates into a very small loss of biomass when considering the study area as a whole.

In summary, the data presented in the above tables reveal the highly dynamic and multi-directional changes that have characterised vegetation modification over the period of study that raise a number of questions concerning the underlying processes supporting these patterns which may challenge the dominant linear narrative of environmental change under rising population numbers. For example, why was there such a small change in 
Table 7

Main sources of wood in Tokwe (percentage of respondents)

\begin{tabular}{|c|c|c|c|c|}
\hline \multirow[t]{2}{*}{ Area } & \multicolumn{4}{|c|}{ Purpose of wood collection } \\
\hline & Cooking & Brewing & Brick making & Construction \\
\hline Devon Ranch & $\mathrm{O}=100$ & $\mathrm{O}=79$ & $\begin{array}{l}F W=52 \\
C W=14 \\
O=24\end{array}$ & $\begin{array}{l}\mathrm{FW}=69 \\
\mathrm{~W}=28 \\
\mathrm{CO}=3.4\end{array}$ \\
\hline The Falls & $\mathrm{O}=100$ & $\begin{array}{l}\mathrm{FW}=5 \\
\mathrm{CW}=24 \\
\mathrm{O}=72\end{array}$ & $\begin{array}{l}F W=50 \\
C W=20 \\
O=30\end{array}$ & $\begin{array}{l}\mathrm{FW}=62 \\
\mathrm{CW}=33 \\
\mathrm{O}=5\end{array}$ \\
\hline
\end{tabular}

FW - Felling wet trees; CW - Cutting wet branches; O - Other sources (dead branches, coppicing, etc).

502 total woodland area, but a large change in distribution? 503 What contextual factors are operating in each village to 504 explain the small change in total open woodland in one 505 area, a loss in the other, and large changes in distribu506 tion in both villages under study? Similarly, why was 507 there a small increase in bushland in one area, a large 508 decrease in the other and such a low overlap in both 509 cases? Furthermore, a linear narrative offers little in 510 terms of an explanation for the small increases in open 511 bushland, but the large variation in the overlaps across 512 the two village areas. Further insight to these questions 513 and their reconciliation may be made through reference 514 to the dynamics of social activity as revealed through 515 field surveys and interviewing that enable both wood516 land losses and expansion.

\subsection{Factors for woodland losses}

Under the land resettlement programme in Zimbabwe to the late 1990s, settlers to the Model A schemes were given permits to cultivate a standard 5 ha (12 acres) of arable land and rights to access communal grazing resources. In contrast, within communal areas, households typically have access to much smaller arable plots and tenure is based on usufruct rights. The extent of common grazing lands in these areas has been declining in recent years (Campbell, 1996). In the interviews conducted with 79 adult members of resettled households in the case villages, over three-quarters reported that it was land shortage in their home areas that had been their primary reason for moving to the Tokwe resettlement scheme. All households reported cultivating an enlarged acreage subsequent to moving to the resettlement areas; over $80 \%$ of households in each case village were utilising their full allocation of 12 acres with the availability of the land in the resettlement scheme given as the main reason for the expansion in cultivation since moving. Ownership of cattle had also increased during the period of resettlement amongst all respondents. Cattle remain one of the principal assets in rural areas of Zimbabwe and as wealth rises, demand for woodland-derived goods necessary for cattle maintenance (for example, graze and browse) and use (poles for kraals or yokes, for example) also increase (Clarke et al., 1996). Long-term panel data for three resettlement scheme areas has confirmed that resettled household are larger, more wealthy and own more cattle than communal area households (Hoogeveen and Kinsey, 2001).

In the course of expanding cultivation, respondents suggested that trees were not always removed from new fields, rather clearing was highly selective as found in the communal areas of Zimbabwe (Campbell et al., 1993; McGregor, 1991) as well as more widely in southern Africa (Munslow et al., 1988). In Devon Ranch, for example, only $11 \%$ of respondents removed trees, the main reason given as the restriction on ploughing caused by stumps and roots. Where trees were left, the main reasons cited were for shade $(48 \%)$, fruits $(19 \%)$, and a combination of factors (11\%). For a small number of respondents, a lack of labour availability was suggested as the reason why trees were left in fields. In The Falls, more respondents $(29 \%)$ removed trees from their farms and again the principal underlying motive for removal was the impediment to ploughing. Here, however, the main reasons for leaving trees in fields were the picking of fruit $(29 \%)$, a lack of labour for clearing $(24 \%)$, shade $(24 \%)$, and fruit and shade considerations (19\%).

In the absence of rural electrification, households remained almost wholly dependent on biomass sources of energy. In the cutting of firewood, rather than the felling of live trees, the main sources were ground collection, dead trees and dead branches. In the corresponding communal areas, households reported a greater dependence on the branches from living trees as well as the collection of dead material; i.e. the greater access to wood in the resettlement areas had reduced the need for live tree cutting. Most of the respondents described access to wood currently as easy (over $90 \%$ in each case) compared with less than $10 \%$ whilst resident in the respective communal areas. Whilst most people considered ease of access to be due to the improved supply and proximity to woodland resources in resettlement areas, the impact of greater resource availability on resource demand was highly varied. In particular, factors of ecology (the location of desired species) and time available in relation to agricultural labour demands 
586 (woodland resources are collected and processed using 587 household labour) were found to mediate the link be588 tween resource supply and demand.

589 It is well known that wood management techniques 590 are highly varied in the communal areas of Zimbabwe 591 (Clarke et al., 1996) and this was evidenced in the di592 verse patterns across and within the resettlement vil593 lages. For example, Table 7 details the source of wood in 594 the two case study areas in relation to different con595 sumption purposes. The felling of wet trees and cutting 596 of wet branches are contrasted with the collection of 597 dead branches and the cutting of dead trees, (the use of 598 living plants being more likely to contribute to defor599 estation). The table shows that the felling of wet trees 600 (the only method that directly reduces tree numbers) 601 was highly variable. In short, it was highest for con602 struction and lowest for cooking consistent with pat603 terns found in communal areas where the range of 604 usable species in construction (species substitutability) is 605 smaller than for fuelwood (Clarke et al., 1996). The 606 cutting of wet branches (coppicing or trimming) was 607 also variable within and between the study areas. This 608 type of activity contributes to the reduction of tree 609 stands to shrub sized growth, and the result may thus be 610 termed mild deforestation.

611 The above figures show that woodcutting was a 612 widespread but socially and spatially variable activity in 613 the case study villages and indeed, fuelwood demand 614 also varied over time. As shown in Table 7, most of the 615 felling of live trees occurred when wood was needed for 616 brick making and construction rather than for more 617 regular demands for fuelwood. Distant places and 618 grazing and riverine areas may thus be inferred as the 619 main areas of tree losses. Where there was a difference 620 between wood harvesting in the communal and reset621 tlement areas, the increased supply of wood in the for622 mer areas was cited as the main factor, followed by 623 access to woodlots, changes in participation and the use 624 of trees felled in the clearance of farms. In all cases there 625 was easier access to trees in the resettlement area than in 626 the communal areas, which had led to more wood being 627 used generally, although over one quarter of respon628 dents reported using less wood currently enabled by the 629 improved supply of required species and desired forms 630 of wood resources currently available.

\subsection{Factors for woodland expansion}

The field survey also revealed a number of factors for woodland expansion such as tree planting. Respondents in the two villages reported widespread tree planting, although the levels of planting and the expressed motivations for it were very varied. Most people in Devon Ranch (57\%) planted two or three trees, typically indigenous fruit trees and usually planted on household 63 dry fields, with the most common reason being for household consumption of fruit products $(82 \%$ of households). In The Falls, a higher proportion of people planted trees and in slightly larger numbers than was common in Devon Ranch. Fruit was again the most common reason for planting $(76 \%)$ and the main areas for planting were the dry fields $(85 \%)$. This level and extent of tree planting in the resettlement cases is much higher than has generally been found in other rural areas of Zimbabwe where typically, between $1 \%$ and $10 \%$ of households have planted indigenous fruit trees (Campbell et al., 1993). Deforestation was not mentioned as a factor influencing tree planting in the study areas except in a small minority of cases, a pattern that has been found in Zimbabwe more widely (Clarke et al., 1996).

Over half of the respondents referred to the existence of woodlots in their area and noted that residents were allowed to use such resources with permission from the resettlement officer (civil servants who constituted the main interface between government and settlers for the first 20 years of the programme, but a position which has now been removed). For trees in homefields and dry fields, male heads were reported to be the main people who took care of these plots and families were the main users. However, for trees in grazing areas there were varied views with regard to the management of the resource and the authority for wood use. This is consistent with what Campbell et al. (2001) has identified as a general pattern for woodland management in Zimbabwe, as being directed at 'those components that are found in privately controlled niches in the landscape' ( $p$. 593). It also confirms wider findings that local control and management of common property resources, including woodlands, are complex and dynamic.

Respondents in the Falls, for example, suggested that the control and authority for management of trees within the grazing areas of their communal homes rested with traditional leaders, but only $6 \%$ suggested that this system continued to be the case in the resettlement area. In Devon Ranch, settlers reported wholly that other agencies, including conservation groups and 'new' local institutional authorities (such as Village Development Committees) now had control and authority. This decline in the importance of traditional control and multiple understandings of where authority lies in regard to common resources is illustrative of what Nhira and Fortmann (1993) referred to a 'special problem' of resettlement scheme areas; the situation whereby the settlement together of households drawn from different locations, traditions and religions tends to weaken traditional controls and often occurs in the absence of any strong externally derived rules or institutions. However, the majority of people within the case studies expressed a confidence regarding the efficacy of their understood systems for woodland management in preventing future deforestation. 
Table 8

Land use in the Tuba/Aplaku plains

\begin{tabular}{|c|c|c|c|c|c|c|}
\hline \multirow{2}{*}{$\begin{array}{l}\text { Settlements } \\
\text { Date }\end{array}$} & \multicolumn{3}{|c|}{ Aplaku/Densu } & \multicolumn{3}{|c|}{ Kokrobite/Oshiyie } \\
\hline & 1960 & 1998 & $\%$ Change & 1960 & 1998 & $\%$ Change \\
\hline $\begin{array}{l}\text { Trees/shrub dominated areas } \\
\text { (woodland, open woodland, } \\
\text { bushland) }\end{array}$ & 52 & 7 & -45 & 66 & 45 & -21 \\
\hline $\begin{array}{l}\text { Grass dominated areas } \\
\text { (open bushland, grassland) }\end{array}$ & 36 & 59 & 23 & 24 & 15 & -9 \\
\hline Cultivation & 4 & 13 & 1 & 5 & 14 & 9 \\
\hline Developers & 1 & 10 & 9 & 1 & 16 & 15 \\
\hline Settlements & 2 & 7 & 5 & 1 & 1 & 0 \\
\hline Other (roads, rivers and beach) & 5 & 4 & -1 & 3 & 9 & 5 \\
\hline
\end{tabular}

In summary these dynamics of social activity and the reported nature, extent and change within livelihood activities of resettled households have confirmed the possibilities for both deforestation and reforestation as revealed and quantified by the GIS analysis. Factors that contribute to the loss of tree stands include the increased cattle herds, increased farm area and easier wood collection. Factors contributing to reforestation include the improved availability of desired species, tree planting and new institutional controls. The following section investigates the possibilities for such an analysis in the coastal savanna of Ghana.

\section{Case study 2. The Tuba/Aplaku plains of coastal Ghana}

\subsection{A narrative}

In Ghana, formerly the British colony of the Gold Coast, the predominant historical narrative is also one
In colonial Ghana, like in the Zimbabwean case and in the wider African situation, the broad mindset of scientific universalism enabled the development of agriculture models with strong environmental consequences. Here, forest reserves were set up widely during the 1920s (Kay, 1972) and have persisted to the current day (Hawthorne, 1994). Other measures taken to arrest environmental degradation during the 1970s and 1980s included the creation of the Anti Bush Fire Law, the National Plan of Action to Combat Desertification (NPACD) and the National Environmental Policy. However, the lack of supporting institutional structures and comprehensive environmental research have limited the impact of these policy actions on the perceived problems of deforestation, soil erosion and ground water depletion and pollution, for example (Campbell, 1994).

Despite the lack of evidence of substantial population movements and resultant conflicts as described in the first case study, marked problems exist in the coastal savanna of Ghana that appear to have resulted in similar environmentally related tensions. Primarily, land use policy issues are concerned with conflicts over land between farmers, developers and the government. Some of these conflicts have involved actual violence, and have led to bans on sales of farmland to developers (Mensah, 1996). In the Densu Ramsar Conservation Area, 'excessive farming' and 'unsuitable fishing methods' as well as the work of developers and particularly the extraction of sand for building are considered to be causing the 'wanton destruction' of this site (Mezikpih, 1996).

\subsection{Time series images and environmental changes}

The second case study area was a $50 \mathrm{sq} \mathrm{km}$ section of the Tuba/Aplaku plains of the coastal savanna of Ghana, located $20 \mathrm{~km}$ southwest of the capital, Accra (Fig. 2). This area contains a number of villages of Bortainor, Oshiyie, Kokrobite, Tuba, Aplaku and Langma, the population of which increased from under 2000 persons in 1948 to over 7000 by 1984 and to an 
Table 9

Transition matrix of land use and vegetation change in Aplaku/Densu (1960-1998)

\begin{tabular}{|c|c|c|c|c|c|c|c|c|c|}
\hline \multirow{2}{*}{$\begin{array}{c}\text { Landscape } \\
\text { features (1998) }\end{array}$} & \multicolumn{8}{|c|}{ Landscape features (1960) } & \multirow{2}{*}{$\begin{array}{l}\text { Total } \\
\text { (1998) }\end{array}$} \\
\hline & Tree/shrub & Grass/shrub & Cultivation & Developers & Settlements & Rivers & Beach & Roads & \\
\hline Tree/shrub & 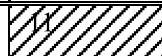 & 2 & 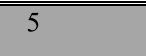 & 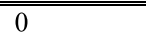 & 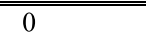 & 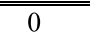 & 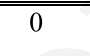 & 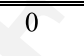 & 7 \\
\hline Grass/shrub & 981117 & 66 & 47 & 0 & 4 & 47 & 65 & 12 & 59 \\
\hline Cultivation & 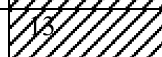 & 158111 & 22 & 0 & 0 & 1 & 0 & 5 & 13 \\
\hline Developers & 48111 & 48111 & 16 & 0 & 0 & 0 & 0 & 2 & 10 \\
\hline Settlements & & 481117 & 10 & 0 & 85 & 0 & 22 & 21 & 7 \\
\hline Rivers & 28 & 11111 & 0 & 0 & 0 & 52 & 12 & 0 & 3 \\
\hline Roads & 0 & 1111 & 0 & 0 & 11 & 0 & 0 & 60 & 1 \\
\hline Beach & 0 & 0 & 0 & 0 & 0 & & 1 & 0 & 0 \\
\hline Total (1960) & 52 & 36 & 4 & 1 & 2 & 2 & 2 & 1 & 100 \\
\hline
\end{tabular}

Deforestation,

Reforestation.

Table 10

Transition matrix of land use and vegetation change in Kokrobite/Oshiyie (1960-1998)

\begin{tabular}{|c|c|c|c|c|c|c|c|c|c|}
\hline \multirow{2}{*}{$\begin{array}{c}\text { Landscape } \\
\text { features (1998) }\end{array}$} & \multicolumn{8}{|c|}{ Landscape features (1960) } & \multirow{2}{*}{$\begin{array}{l}\text { Total } \\
\text { (1998) }\end{array}$} \\
\hline & Tree/shrub & Grass/shrub & Farms & Developers & Settlements & Rivers & Beach & Roads & \\
\hline Tree/shrub & 47 & 45 & $\overline{60}$ & 0 & 17 & 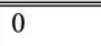 & 0 & 0 & 45 \\
\hline Grass/shrub & BEDIDII & 19 & 6 & 0 & 10 & 0 & 0 & 20 & 15 \\
\hline Farms & & BADIDID & 18 & 0 & 0 & 0 & 0 & 8 & 14 \\
\hline Developers & & 5891919 & 14 & 0 & 0 & 0 & 0 & 9 & 16 \\
\hline Settlements & 0 & $8 D 1111$ & 1 & 0 & 30 & 0 & 0 & 3 & 1 \\
\hline Rivers & 0 & 0 & 0 & 0 & 0 & 0 & 0 & 0 & 0 \\
\hline Beach & QDDIDIII & DADIDID & 0 & 0 & 41 & 0 & 0 & 6 & 5 \\
\hline Roads & & $58 D=111$ & 1 & 0 & 2 & 0 & 0 & 34 & 4 \\
\hline Total (1960) & 66 & 24 & 5 & 1 & 1 & 0 & 1 & 1 & 100 \\
\hline
\end{tabular}

770 excess of 10,000 by 1996 (Campbell, 1998). The annual 771 rainfall of the Tuba/Aplaku plains area is between 500 772 and $600 \mathrm{~mm}$, and the soils are mainly ultisols, entisols 773 and alfisols, overlying igneous and metamorphic rocks. 774 The area is generally undulating topography, lying be775 low $300 \mathrm{~m}$ elevation. The vegetation is a patch mosaic of 776 trees, shrubs and grasses, mostly Azadirachta indica, 777 Mangifera indica, Andropogon guyanus and Panicum 778 maximum. Households in the area typically base their 779 livelihoods on a combination of farming, hunting, fish780 ing, firewood cutting, and trading in food and non-food 781 items. Land use disputes are common in the area, and these have had pronounced social, political, economic 782 and environmental externalities such as in Bortianor where such conflicts revolved around the sales of cultivated farmland by traditional authorities to developers and resulted in riots (Campbell, 1998). A comparison with the Zimbabwean case therefore shows some similarity in that a region covered by patch mosaic of trees, shrubs and grass, arguably the relic of richer vegetation, has been the scene of stakeholder conflicts in which the result has been complex multi-directional environmental change. 
Table 11

Vegetation dynamics in Tuba/Aplaku

\begin{tabular}{|c|c|c|}
\hline \multirow[t]{2}{*}{ Vegetation type and land use } & \multicolumn{2}{|c|}{ Evidence of dynamics area and percentage change (1960-1998) } \\
\hline & Aplaku/Densu & Kokrobite/Oshiyie \\
\hline Woodland/open woodland/bushland & Large reduction $(52-7 \%)$. Small overlap $(11 \%)$ & $\begin{array}{l}\text { Moderate reduction }(66-45 \%) \text { Moderate over- } \\
\text { lap }(47 \%)\end{array}$ \\
\hline Open bushland/grass land & $\begin{array}{l}\text { Moderate increase }(36-59 \%) \text {. Moderate overlap } \\
(66 \%)\end{array}$ & $\begin{array}{l}\text { Moderate reduction }(24-15 \%) \text { Small overlap } \\
(19 \%)\end{array}$ \\
\hline Cultivation & Small increase (4-13\%) Small overlap (22\%) & Small increase (5-14\%) Low overlap (18\%) \\
\hline
\end{tabular}

Table 12

Deforestation/reforestation in different contexts

\begin{tabular}{|c|c|c|c|c|}
\hline \multirow[t]{2}{*}{ Former vegetation } & \multicolumn{2}{|c|}{$\begin{array}{l}\text { Tree loss }(1960-1998) \text { as percentage of total } \\
\text { percentage of features in column }\end{array}$} & \multicolumn{2}{|c|}{$\begin{array}{l}\text { Tree gain (1960-1998) as percentage of total } \\
\text { percentage of features in column }\end{array}$} \\
\hline & Aplaku/Densu & Kokrobite/Oshiyie & Aplaku/Densu & Kokrobite/Oshiyie \\
\hline Open bushland/grassland & 31 & 11 & 1 & 11 \\
\hline Cultivation & 7 & 7 & 0.2 & 3 \\
\hline Developers & 7 & 15 & 0 & 0 \\
\hline Settlements & 2 & 0 & 0 & 0.2 \\
\hline Total tree loss as $\%$ of total area & 47 & 33 & 1.2 & 14.2 \\
\hline
\end{tabular}

Note: the vegetation classified as Forest includes the categories: woodland, open woodland and bushland (tree/shrub mosaic).

In the same manner as for the Zimbabwe case study, the output maps of the aerial photograph interpretation were digitised and analysed using GIS techniques. Two sample sites, the Aplaku/Densu and the Kokrobite/ Oshiyie environs, were selected from the wider study. Table 8 shows the linear changes in land use over the study period. It is apparent that there is greater deforestation here than in the Zimbabwean case (over $20 \%$ change as opposed to less than $5 \%$ ) and there are quite different trajectories of grassland change. In the Zimbabwean cases, there had been losses of between $4 \%$ and $10 \%$, but in the Ghanaian examples, grass dominated areas expanded very significantly in Aplaku/Densu, but declined in Kokrobite/Oshiyie by 9\%. These differences, as argued in the next sections reflect slight differences in the intensity of the human activities.

Tables 9-11 are the matrices generated through IDRISI that express the multi-directional nature of environmental change and point to the more complicated story of land use in the two sample sites. In Table 9, the first column for example, shows that $59 \%$ of the lands in Aplaku/Densu that were under tree/shrubland in 1960 were defined as grass/shrubland in 1998 indicating some deforestation possibly representing the short fallows of farming, loss through firewood cutting or via the activities of developers. The gross increase in grassland/ shrubland in the area is also shown, rising from $36 \%$ in 1960 to $59 \%$ in 1998 . Table 10 shows the very contrasting situation in the Kokrobite/Oshiyie region in terms of these same land use changes; there was a much smaller loss of woodland to grassland $(16 \%)$ and an overall loss of grassland from $24 \%$ of the total area in 1960 to $15 \%$ in 1998 .

Table 11 provides further illustration of the complexities of landscape change through highlighting the variable overlaps between the extent of the classified associations in 1960 and 1998. As discussed previously, where there is a large overlap between similarly classified areas across the two dates, it implies that there has been little change in either land use or the spatial distribution of a particular land use category. However, where there is a small overlap between, for example, forested areas in 1960 and 1998 the implication is that land use patterns between the two dates have been spatially variable. This may have allowed new tree growth in some areas, which may balance deforestation in other areas. Such changes would be less obvious where total figures were considered, but easily appraised where multi-directional change could be documented.

Combining the insights of these tables, it is seen that in the Aplaku/Densu area, wooded areas were reduced very markedly and the overlap very small (Table 11 ). Over one-quarter of total woodland losses were to developers and to cultivation (in equal measure) as shown in Table 9, however, the major woodland losses were to grass dominated vegetation as already discussed. Counteracting these changes were the tree/shrub growths that replaced $5 \%$ of former farmland and $2 \%$ of grassland as also shown in Table 9 (columns 3 and 2, respectively). In the Kokrobite/Oshiyie area, there was a 
853 much larger overlap in terms of woodland areas $(47 \%)$

854 and a much smaller reduction in forested areas over the 855 period in comparison to the Aplaku/Densu case. Over856 laps for grassed areas $(19 \%)$ and for cultivated areas $857(18 \%)$ were much smaller than for woodland in Kokr858 obite/Oshiyie and smaller in comparison to the Aplaku/ 859 Densu area experience in these terms. Woodland losses 860 in this case area were more evenly spread; being to grass 861 dominated vegetation (16\%), farms (11\%) and develop862 ers $(23 \%)$ in the main (Table 10$)$. There were also gains 863 in woodland via tree/shrub expansion into formerly 864 grass-dominated areas $(45 \%)$ and on farmlands $(60 \%)$.

865 Table 12 shows the actual percentage expansion and 866 retraction of wooded areas, in relation to other land867 scape features (open bushland, grassland, cultivated 868 areas and settlements). As in the Zimbabwe case and as 869 revealed in the matrices above, in most cases both de870 forestation and woodland expansion were apparent, 871 despite the evidence that in terms of gross change, de872 forestation was more noticeable.

873 In summary and in continuity with the Zimbabwean 874 case, the data indicates that a more comprehensive as875 sessment and analysis of vegetation change is possible 876 only when multi-directional and spatially variable 877 change is documented using GIS methods. In these two 878 cases the dynamics of change documented by the anal879 ysis of the time series images preclude the linear change 880 hypothesis dominant in scientific and policy circles and 881 raise questions including why was there a much larger 882 change in woodland in Aplaku/Densu than in the 883 Kokrobite/Oshiyie example, and such small overlaps in 884 both cases? Further differences between the case study 885 areas that require explanation include the large losses of 886 grass-dominated and farmland areas to woodland in 887 Kokrobite/Oshiyie compared to much smaller losses in 888 Aplaku/Densu. Similarly, why was there an increase 889 (and a large overlap) in grassland in Aplaku, but a de890 cline (and a small overlap) in Kokrobite/Oshiyie?

891 These questions may be answered in a similar fashion 892 to those posed in relation to the Zimbabwean case 893 study. Human activities change the landscape in many 894 ways and these may cause both degradation and en895 richment. Environmental change can only be under896 stood through an assessment that includes these 897 dynamics of human activity as revealed in this study 898 through informal interviewing at the household and 899 community levels.

\section{4.3. Factors for woodland losses}

901 In coastal Ghana there was evidence of a greater 902 variation of farming types than in the resettlement area 903 of Zimbabwe (where the 'model' for agricultural pro904 duction has been more closely controlled). This has 905 translated into more complex environmental outcomes 906 in Ghana. Respondents in the field argued regularly for the expansion of permanent cultivation (as contrasted to shifting cultivation, the balance between the two creating complex variations) as the principal factor explaining woodland loss over previous decades. Shifting cultivation was detailed as a common practice in the past, although this had gradually declined during the 1980s. Under this system, land cultivated for several years would be left fallow for 3-5 years with the objective of recovering soil fertility. Extensive shifting cultivation over the period under study would therefore modify areas dominated by older forest, creating a patch mosaic of trees, shrubs and grasses, as fallowing of this length enabled some regrowth to shrub sized trees. However, as population increased in the area, more land was needed and respondents reported landowners as becoming more reluctant to lease land to farmers. The result was the collapse of the shifting cultivation system by the mid-1980s in favour of intensively cultivated permanent plots. After this period, farms could still be left fallow for long periods, but the common reasons for such practice were farm abandonment (as people sought the promise of alternative livelihoods), land purchases by developers, and/or permanent moves in response to desiccation, erosion and severe fertility decline in the area. All the respondents who had practised farming, fishing, trading and/or wood cutting (about 95\%) argued that they had practised multiple activity livelihoods for at least one season during their life in the area.

A further reported change in farming activity was the increase in farm diversification across the period. In this system, farmers cultivated widely spaced plots, usually as a coping strategy in reaction to the threat of loss of one farm to desiccation, water logging, fire, rodents/insects or external developers. $30 \%$ of respondents in the sample argued that they had farms in widely spaced areas and the main reason given was the fear of the loss of cultivated plots to such localised problems. Other farmers stated that they knew that this strategy was a good method for ensuring the retention of at least one plot when another plot was lost, even though they did not practise it themselves. Lack of land and physical effort were cited as discouraging factors.

Wood was the main fuel source in the area. In the survey, $40 \%$ of the total sample said they participated in woodcutting. Of these, 52\% admitted regular woodcutting (almost wholly women) and indeed, defined themselves as woodcutters in the sense that they practised part time cutting and trading during the farming season and then engaged full time in woodcutting and sales during the dry season. The remaining $48 \%$ of the sample participated in sporadic cutting for household use. 3-5 trips would be made each week and headloading (either tied bundles of small branches or carried in large aluminium pans on the head) were the main transport system. Small wheeled carts were used in most instances were roots and larger stumps were transported. 
Respondents reported a range of management tech964 niques in relation to fuelwood cutting. In approximately 965 one fifth of cases, collection was of dead branches and 966 from the cutting of dead trees. Selective coppicing was 967 also practised widely and total stem extraction and root 968 digging of live trees on a smaller scale. The main source 969 areas were farms (farmers argued that about one third of 970 their needs were from this source, especially where the 971 fallow was long), as well as from forest clumps, grazing 972 and other non-farmed areas.

973 The distances covered to collect adequate wood 974 supplies in the area had increased from less than $2 \mathrm{~km}$ in 975 the 1970 s to between 4 and $10 \mathrm{~km}$ in the mid-1990s. In 976 some cases due to the scarcity of wood, trees were cut 977 over $100 \mathrm{~km}$ away and transported by truck to the vil978 lages. Respondents identified population increase and 979 the expansion of fishsmoking as a livelihood option for 980 women as factors in both deforestation (in the case of 981 the total plant removal method) and the increased pat982 ches of shrub sized tree species in areas already bearing 983 the imprints of farming.

984 A further factor for woodland losses was hunting, 985 which is a fairly common element in local livelihoods. 986 The main contexts for hunting were woodland and 987 bushland and particularly on hilly slopes where farming 988 was more restricted, vegetation thicker and antelope 989 (various species of duika and bushbuck in the main) 990 more common. Hunting was considered to contribute to 991 deforestation largely through the practice of bush 992 burning (employed to flush out the game). In some cases 993 up to two hectares could be burnt in a single day. 994 However, respondents blamed farming, settlement ex995 pansion and firewood cutting for the perceived habitat 996 loss in the area, the impacts of which were reportedly 997 felt in terms of the shifting of hunting grounds to more 998 marginal, steeper slopes where farming is less prevalent 999 but where 'catches' were falling over time.

1000 Increased cattle ownership was also evident. A small 1001 number of farmers held relatively large stocks of cattle 1002 (45 individuals owning on average 100 head). Sheep, 1003 goats and pigs are also kept on a small scale. Preferred 1004 grazing areas for livestock were the shrub/grass mosaics 1005 (open bushland) and over 70\% of the respondents in the 1006 survey mentioned cattle grazing on seedlings and shrub 1007 sized trees as a factor for deforestation.

\section{4.4. Factors for woodland expansion}

1009 As in the Zimbabwean case, there was evidence of 1010 woodland expansion. Here, however, this was due 1011 principally to the common practice of farm abandon1012 ment, rather than extensive tree planting. $80 \%$ of farm1013 ers had abandoned their plots for some time (a few 1014 months to over a decade), the main reasons being to 1015 take on alternative or replacement livelihood activities 1016 (whether on a temporary, semi-permanent or permanent basis). Similarly, the purchase of farmland by developers would result in the immediate cessation of cultivation and commonly, building in developers' plots would be delayed as owners rarely had enough cash for ready progress and sometimes land would be purchased with the intention of a later resale at a profit. Both scenarios enable fallow regrowth of shrubs and trees and these areas were utilised by firewood cutters, and where there was animal re-colonisation, by hunters.

A further factor in maintaining woodland status was the continued prevalence of fetish power in the area. Respondents in the survey identified four fetish groves where traditional religious authorities had the power to prohibit farming, woodcutting and hunting in certain areas believed to be inhabited by gods. The prohibition of land use in these areas allows the regrowth of forest. Despite a gradual exploitation of the edges of some of the fetish groves, more than $80 \%$ of the respondents admitted that they would not farm or otherwise exploit the groves, even though most of the people privately said they did not believe the power of the "touch it and die" edict of the priest. Changing cultural patterns (Islam and Christianity, Western science and materialism, and declining respect for rural traditions) were recognised by all the respondents as factors that may contribute to the eventual demise of fetish groves.

Woodlots also existed, but unlike in the Zimbabwean case, these were limited to four fixed plots, rather than in dispersed locations. Therefore, the contribution of these woodlots were more locationally specific. The woodlots were planted by the Forestry Department and fishsmokers in the area in the early 1990s. Each lot is about half a hectare and has about 40 trees (all Casia simea). The local farmers and fishsmokers maintained these areas. Occasional trimming of branches is allowed but all the respondents agreed that regular woodcutting was prohibited, and this edict was generally obeyed.

These activities illustrate the reforestation possibilities in local land use patterns and support the position that land use intensification does not necessarily contribute to deforestation. As was also revealed in the Zimbabwean cases, land use variations created spatial variations in vegetation degradation and enrichment. Enrichment in both cases involved variable activities: tree planting and in the Ghanaian cases farm abandonment and traditional protection schemes. However, as argued below, the impacts of these activities were sufficient to create changes of such complexity, that a linear sequence of vegetation modification was difficult to discern. A closer comparison of the evidence presented above illustrates this point further. 
1068 5. A comparison of the cases and the implications for 1069 wider research

1070 A comparison of the received narratives of historical 1071 landscape change in Zimbabwe and Ghana revealed that 1072 in both cases, there has been an historical assessment of 1073 gradual environmental degradation, manifested largely 1074 by deforestation and soil erosion. The transition in both 1075 cases is from a largely forested biome, to a tree and grass 1076 patch mosaic and political and economic factors are the 1077 main issues at stake, rather than ecological factors. 1078 Despite slightly different sets of stakeholders, power 1079 relations were essentially similar; the local farmers and 1080 foreign dominated large-scale farming and mining in1081 terests were in clear competition for arguably insufficient 1082 land resources. Furthermore, the marginalisation of the 1083 former did not prevent these local groups being blamed 1084 for the degradation, despite evidence of shared respon1085 sibility. Similarly, in both cases, there has been no evi1086 dence of a counternarrative of environmental change, 1087 where human activities have reversed trends of land1088 scape degradation, or even created new enriched forms.

1089 The detail presented for the case studies concerning 1090 the forms and factors for multi-directional environ1091 mental change also revealed similarities across the study 1092 areas. For example, in both cases there are two main 1093 activities that contribute to deforestation, woodcutting 1094 and farming. In terms of reforestation and environ1095 mental enrichment, the field studies also revealed that 1096 these activities were not wholly destructive, with evi1097 dence of tree planting in Zimbabwe and farm aban1098 donment and land protection in Ghana, for example. In 1099 both cases these activities were not imposed by powerful 1100 stakeholders, but emerged from the local context, as a 1101 response by the local people to perceived environmental 1102 issues and livelihood opportunities. Externally derived 1103 environmental management increased, rather than 1104 solved environmental problems and may be seen as 1105 factors behind the development of coping strategies 1106 among the local people. Therefore, the role of local 1107 actors in landscape enrichment appears in these contexts 1108 to be indicative of an understanding of the concept of 1109 environmental renewal among local actors, and provides 1110 evidence that the blame assigned to these people for 1111 degradation in the conventional narrative was at least 1112 partially misplaced.

1113 In the larger sense of the implications for rural Af1114 rica, these findings do not entirely refute established 1115 narratives of linear complex change, rather they contest 1116 the predominant narratives in terms of both the con1117 tributory factors for change and the direction of change.

1118 The analysis presented here thus opens a wider debate

1119 that must assess more evidence. Useful information

1120 could be derived from more comprehensive time series 1121 images (including, for example, more recent photogra1122 phy in the Zimbabwean case which may capture the differences between 'one-off' responses to population movement and longer term resource management decisions), longer term field studies, and a larger number of case studies. However, the use of two widely spaced sets of air photos (as was the case in the studies by Fairhead and Leach, 1995, and Tiffen et al., 1994) was revealed to be appropriate for the study of 'landscape' level changes such as in woodland status and of 'longer term' social dynamics such as settlement expansion. In both case studies the lack of detailed information on environmental change (resulting in disputes and the ill-informed apportionment of blame) was a major constraint to effective rural policy. The multiple tool methodology employed in this paper has certainly enabled a more accurate identification of the spatial patterning of those features that represent or reveal the human imprint on the landscape at a number of scales.

From a methodological perspective it has also been demonstrated that GIS techniques can readily produce results which support the attempts by current researchers to investigate the complex dynamics at the socioenvironmental interface. For social scientists the strength of this methodology lies in its ability to represent the results of human impacts on the environment as multidirectional change. The methodology also proved supportive of the ecological disequilibrium paradigm in new ecological theory, which emphasises multi-state and unpredictable changes in vegetation distribution. The results displayed in the matrices, for example, provide evidence for multi-directional changes, and can portray the dynamics of disequilibrium more effectively than linear graphs.

The current study has provided one more step forward in answering the question of whether the current knowledge of the rural socioenvironmental dynamics in these contexts is sufficient to explain observed landscape changes. The answer was no, and evidently new studies are needed. Nevertheless, by demonstrating how this question may be answered at the landscape level over the medium term, groundwork was provided for studies at more detailed scales and in more contexts across Africa.

\section{References}

Batterbury, S.P.J., Bebbington, A.J., 1999. Environmental histories, access to resources and landscape change: an introduction. Land Degradation and Development 10 (4), 279-289.

1166

1167

1168

Batterbury, S., Forsyth, T., Thomson, K., 1997. Environmental 1169 transformations in developing countries: hybrid research and 1170 democratic policy. The Geographical Journal 163 (2), 126-132. 1171

Beinart, W., 1984. Soil erosion, conservationism and ideas about 1172 development: a Southern African exploration, 1900-1960. Journal 1173 of Southern African Studies 11 (1), 52-83. 1174

Beinart, W., 2000. African history and environmental history. African 1175 Affairs 99, 269-302. 
Hoogeveen, J.G.M., Kinsey, B.H., 2001. Land reform, growth and equity: emerging evidence from Zimbabwe's resettlement programme. A sequel. Journal of Southern African Studies 27 (1), 127136.

Howard, R., 1978. Colonialism and Underdevelopment in Ghana. Croon Helm, London.

Ihse, M., 1994. Landscape ecology mapping and evaluation of small biotopes in the Swedish Agricultural Landscape by visual remote sensing a pilot project. In: Remote Sensing in Landscape Ecological Mapping Report EUR 16265. EN European Commission, Brussels, pp. 91-99.

Innes, J.L., 1998. Measuring environmental change. In: Peterson, D.L., Parker, V.T. (Eds.), Ecological Scale: Theory and Applications. Columbia University Press, New York, pp. 429-457.

Jensen, J.R., 1996. Introductory Digital Image Processing; A Remote Sensing Perspective, second ed. Prentice-Hall, Upper Saddle River, NJ.

Campbell, M., 1998. Interactions between biogeography and rural livelihoods in the coastal savanna of Ghana. Unpublished Ph.D. Thesis, University of London.

Clarke, J., Cavendish, W., Coote, C., 1996. Rural households and miombo woodlands: use, value and management. In: Campbell, B.M. (Ed.), The Miombo in Transition: Woodlands and Welfare in Africa, pp. 101-136.

Cliffe, L., 1988a. The conservation issue in Zimbabwe. Review of African Political Economy 42, 48-57.

Cliffe, L., 1988b. Zimbabwe's agricultural success. Review of African Political Economy 43, 48-58.

Commercial Farmers Union, 1991. The land issue. Paper presented to the General Meeting of the CFU, Harare, January 11, 1991.

Collins, J.B., Woodcock, C.E., 1996. An assessment of several linear change detection techniques for mapping forest mortality using multitemporal landsat TM data. Remote Sensing of the Environment 56, 66-77.

Crummey, D., 1998. Deforestation in Wallo. Journal of Ethiopian Studies 21 (11), 1-41

Dickson, K.B., Benneh, G., 1988. A New Geography of Ghana. Longman, London.

Elliott, J.A., 1991. Environmental degradation, soil conservation and the colonial and post-colonial state in Rhodesia/Zimbabwe. In: Dixon, C., Heffernan, M. (Eds.), Colonialism and Development in the Contemporary World. Mansell, London, pp. 72-91.

Elliott, J.A., 1994. The sustainability of household responses to fuelwood needs in the resettlement areas of Zimbabwe: a preliminary report of survey findings. Occasional Papers: New Series A: Geographical Research No.3. Staffordshire University, Stoke-onTrent.

Elliott, J.A., 1995. Processes of interaction across resettlement and communal area boundaries in Zimbabwe. Geographical Journal of Zimbabwe 26, 1-16.

Fairhead, J., Leach, M., 1995. False forest history, complicit social analysis: rethinking some west african environmental narrative. World Development 23 (6), 1023-1035.

Fairhead, J., Leach, M., 1998. Reframing Deforestation. Global Analysis and Local Realities: Studies in West Africa. Routledge, London.

Government of Zimbabwe, 2001. Land Reform and Resettlement Programme Revised Phase II. Ministry of Lands, Agriculture and Rural Resettlement, Harare.

Haberl, H., Batterbury, S., Moran, E., 2001. Using and shaping the land: a long-term perspective. Land Use Policy 18, 1-8.

Harts-Broekhuis, A., Huisman, H., 2001. Resettlement revisited: land reform results in resource-poor regions in Zimbabwe. Geoforum $32,285-298$

Hawthorne, W.D., 1994. Fire Damage and Forest Regeneration in Ghana: Forestry Inventory and Management Project of the Ghana Forestry Department. Overseas Development Administration, London.

Kay, G.R., 1972. The Political Economy of Colonisation in Ghana: A Collection of Documents and Statistics 1900-1960. Cambridge University Press, London.

Kinsey, B.H., 1997. Land reform, growth and equity: emerging evidence from Zimbabwe's resettlement programme. Journal of African Studies 25 (2), 173-197.

Klepeis, P., Turner II, B.L., 2001. Integrated land history and global science: the example of the Southern Yucatan peninsular region project. Land Use Policy 18, 27-39.

Leach, M., Mearns, R., 1996. The Lie of the Land: Challenging Received Wisdom on the African Environment. James Curry, London.

Lieberman, D.D., 1979. Dynamics of forest and thicket vegetation on the Accra Plains, Ghana. Unpublished Ph.D. Thesis, University of Ghana.

Lindblade, K.A., Carswell, G., Tumuhairwe, J.K., 1998. Mitigating the relationship between population growth and land degradation. Ambio 27 (7), 565-571.

McGregor, J., 1991. Woodland resources: ecology, policy and ideology. A historical case study of woodland use in Shurugwi communal area, Zimbabwe. PhD. Thesis, Loughborough University of Technology.

McGregor, J., 1995. Conservation, control and ecological change: the politics and ecology of colonial conservation in Shurugwi, Zimbabwe. Environment and History 1, 257-299.

Millington, A.C., Styles, P.J., Critchley, R.W., 1992. Mapping forests and savannas in Sub-Saharan Africa from advanced very high resolution (AVHRR) imagery. In: Furley, P.A., Proctor, J., Ratter, J.A. (Eds.), Nature and Dynamics of Forest-Savanna Boundaries. Chapman \& Hall, London, pp. 37-62.

Mensah, G.E., 1996. Minister freezes sale of bortianor lands. Ghanaian Times, 3.

Mezikpih, E., 1996. Ban on sale of bortianor lands. Daily Graphic, 8

Munslow, B., Katerere, Y., Ferf, A., O'Keefe, P., 1988. The Fuelwood Trap: A Study of the SADCC region. Earthscan, London.

Nhira, C., Fortmann, L., 1993. Local woodland management: realities at the grassroots level. In: Bradley, P.N., McNamara, K. (Eds.), Living With Trees: Policies for Forestry Management in Zimbabwe. World Bank Technical Paper No. 210. World Bank, Washington, pp. 139-155.

Nicolis, G., 1994. Dynamical systems, biological complexity and global change. In: Solbrig, O.T., Van Emden, H.M., Oordt, P.G.W.J. (Eds.), Biodiversity and Global Change. CAB International, Wallingford, pp. 21-31.

Nsiah Gyabaah, K., 1992. Environmental degradation and the threat of drought and desertification in the Upper West Region of Ghana: a search for sustainable development solutions. Unpublished Ph.D. Thesis, University of London.

Oduro-Afriyie, K., 1996. Rainfall erosivity map for ghana. Geoderma $74(1-2), 161-166$ 
1311 Phimister, I., 1986. Discourse on the discipline of historical context: 1312 conservationism and ideas about development in Southern Rho1313 desia 1930-1950. Journal of Southern African Studies 5 (2), 2631314275.

1315 Pickett, S.T.A., Parker, V.T., Fiedler, P.L., 1992. The new paradigm in 1316 ecology: implications for conservation biology above the species 1317 level. In: Fiedler, P.L., Jain, K. (Eds.), Conservation Biology: The 1318 Theory and Practice of Nature Conservation, Preservation and 1319 Management. Chapman \& Hall, NewYork, pp. 66-87.

1320 Roscoe, J.H., 1960. In: Photographic Interpretation in Geography. 1321 Manual of Photographic Interpretation. American Society of 1322 Photogrammetry, New York, pp. 735-792.

1323 Rowe, J.S., 1997. From reductionism to holism in ecology and deep 1324 ecology. The Ecologist 27 (4), 147-151.

1325 Rubben, E.L., 1960. In: Photographic Interpretation in Geography. 1326 Manual of Photographic Interpretation. American Society of 1327 Photogrammetry, New York, pp. 99-168.

1328 Salami, A.T., 1999. Vegetation dynamics on the fringes of lowland 1329 1330 1331 1332 1333 1334 1335 of environmental change with air photos and landsat TM. Journal of Remote Sensing 20 (6), 1169-1181.

Scoones, I., 1995. Politics, polemics and pastures: range management science and policy in Southern Africa. In: Leach, M., Mearns, R. (Eds.), The Lie of the Land: Challenged Received Wisdoms in Africa Environmental Change and Policy. James Currey, London.
Scoones, I., 1997. The dynamics of soil fertility change: historical perspectives on environmental transformation from Zimbabwe. The Geographical Journal 63 (2), 161-169.

Scoones, I., 1999. New ecology and the social sciences: What prospects for a fruitful engagement? Annual Review of Anthropology 28, 479-507.

Singh, A., 1989. Digital change detection techniques using remotelysensed data. International Journal of Remote Sensing 10 (6), 9891003.

Solbrig, O.T., 1993. Ecological constraints to savanna land use. In: Young, M.D., Solbrig, O.T. (Eds.), The World's Savannas: Economic Driving Forces, Ecological Constraints and Policy Options for Sustainable Land Use. Pantheon Publishing Group, Paris, pp. 21-47.

Sullivan, S., 1996. Towards a nonequilibrium ecology: perspectives from an arid land. Journal of Biogeography 22, 1-5.

Tiffen, M., Mortimore, M., Gichuki, F., 1994. More People, Less Erosion: Environmental Recovery in Kenya. Wiley, Chichester.

Vadya, A.P., Walters, B.B., 1999. Against political ecology. Human Ecology 27 (1), 167.

1336

1337

1338

1339

1340

1341

1342

1343

1344

1345

1346

1347

1348

1349

1350

1351

1352

1353

1354

1355

Whitlow, J.R., 1988. Land Degradation in Zimbabwe: A Geographical 1356 Study. Department of Natural Resources/University of Zimbabwe, 1357 Government Printer, Harare.

1358

World Bank, 1999. Project Appraisal Document on a proposed 1359 learning and innovation loan to the Republic of Zimbabwe for land 1360 reform (inception phase) Support Project. Agriculture and Rural 1361 Development, Africa Region. 